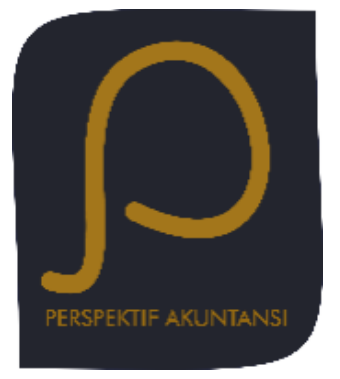

Perspektif Akuntansi

Volume 3 Nomor 2 (Juni 2020), hal. 109-124

ISSN: 2623-0194 (Print), 2623-0186 (Online)

Copyright(C) The Authors(s). All Rights Reserved

Fakultas Ekonomika dan Bisnis,

Universitas Kristen Satya Wacana

DOI: https://doi.org/10.24246/persi.vXiX.p109-124

http://ejournal.uksw.edu/persi

\title{
Expense Ratio, Portfolio Turnover dan Return Reksa \\ Dana Saham
}

\author{
Arlians Rolank Habba Lagu ${ }^{1}$ \\ Universitas Kristen Satya Wacana
}

Received Abstract. This research aims to test the effect of expense ratio and portfolio 13/03/2020 turnover on stock mutual fund returns. Furthermore, this study uses Markowitz's portfolio theory (1952). This study uses secondary data Accepted obtained from OJK and websites (bareksa and fund markets) from the 201620/05/2020 2018 period. By using a quantitative method in the form of a classic assumption test and a regression test, this study shows that the expense ratio has a significant negative effect on stock mutual fund returns. Meanwhile, turnover portfolio does not significantly influence the return of equity funds.

Keywords: expense ratio, portfolio turnover, return rate, equity funds.

\begin{abstract}
Abstrak. Penelitian ini bertujuan menguji pengaruh antara expense ratio dan portfolio turnover terhadap return reksa dana saham. Selanjutnya penelitian ini menggunakan teori portofolio Markowitz (1952). Penelitian ini menggunakan data sekunder yang didapatkan dari OJK dan website (bareksa dan pasar dana) dari periode 2016-2018. Dengan menggunakan metode kuantitatif berupa uji asumsi klasik dan uji regresi, penelitian ini menunjukkan bahwa expense ratio berpengaruh signifikan negatif terhadap return reksa dana saham. Sedangkan, portfolio turnover tidak berpengaruh signifikan terhadap return reksa dana saham.
\end{abstract}

Kata kunci: expense ratio, portfolio turnover, return, reksa dana saham.

\section{Pendahuluan}

Indonesia mengenal reksa dana sebagai wadah yang digunakan untuk menghimpun dana masyarakat yang menginvestasikan modalnya kedalam efek

\footnotetext{
1 alriansrolank@gmail.com
} 
yang akan dikelola oleh manajer investasi (Harjono, et al., 2017). Reksa dana berpatokan terhadap UU No 8 tahun 1995 tentang pasar modal, sehingga banyak masyarakat yang mengenal reksa dana sebagai tempat investasi yang paling cocok untuk menginvestasikan modalnya dengan baik. Indonesia memiliki jumlah penduduk yang mencapai 264 juta penduduk, dengan sejumlah 70 juta penduduk dari kelas menengah. Akan tetapi, jumlah investor yang berinvestasi di pasar modal Indonesia tidak lebih dari 1,6 juta penduduk dan untuk reksa dana dengan jumlah yang tidak lebih dari 988 ribu penduduk Indonesia (KSEI, 2018).

Reksa dana memiliki kelebihan dalam menarik investor untuk berinvestasi di pasar modal. Pertama, tingkat likuiditas yang dihasilkan reksa dana merupakan tingkat likuiditas yang tinggi, hal ini dapat memudahkan investor menjual dan membeli reksa dana pada harga umum yang berlaku. Kedua, reksa dana juga, dapat memberikan tingkat keuntungan hingga 20\% pertahun secara rata-rata. Salah satu reksa dana yang menghasilkan keuntungan besar adalah reksa dana saham. Ketiga, reksa dana dapat displit atau dibagi-bagi dalam pecahan yang kecil, hal ini dapat membantu investor untuk meminimalkan risiko melalui diversifikasi investasi secara optimal. Keempat, risiko pada reksa dana jika dikelola dengan baik, maka dapat memberikan keuntungan investasi dimasa yang akan datang (Wibowo, 2011).

Penelitian yang dilakukan oleh Lohana (2013) menyatakan bahwa return reksa dana pada negara berkembang, cenderung memiliki indeks return yang lebih tinggi meskipun pasar tidak menunjukkan tingkat yang tidak terlalu tinggi. Fan (2016) menyatakan bahwa rasio turnover yang berdasarkan terhadap jual dan beli reksa dana, menunjukkan bahwa kinerja manajer investasi dapat dipengaruhi ketika risiko yang ditunjukkan lebih rendah. Manajer investasi memiliki kinerja yang berpengaruh besar terhadap kinerja reksa dana saham (Sari dan Purwanto, 2012).

\section{Tabel 1. Penelitian Terdahulu}

\begin{tabular}{|c|c|c|c|}
\hline No & Penelitian & Variabel & Hasil \\
\hline 1 & $\begin{array}{l}\text { See dan Jusoh, } \\
\text { (2012) }\end{array}$ & $\begin{array}{l}\text { Pengaruh portfolio } \\
\text { turnover }\end{array}$ & $\begin{array}{l}\text { Turnover berpengaruh } \\
\text { negatif tidak signifikan }\end{array}$ \\
\hline 2 & $\begin{array}{l}\text { Putri dan } \\
\text { Haryanto, } \\
(2014)\end{array}$ & Pengaruh expense ratio & $\begin{array}{c}\text { Expense ratio berpengaruh } \\
\text { negatif signifikan }\end{array}$ \\
\hline 3 & $\begin{array}{l}\text { Mulyawan, } \\
\text { (2016) }\end{array}$ & $\begin{array}{c}\text { Pengaruh expense ratio } \\
\text { Pengarus Portfolio turnover }\end{array}$ & $\begin{array}{c}\text { Expense ratio berpengaruh } \\
\text { negatif signifikan } \\
\text { Portfolio turnover } \\
\text { berpengaruh positif } \\
\text { signifikan }\end{array}$ \\
\hline 4 & $\begin{array}{l}\text { Satrio dan } \\
\text { Mahfud, } \\
(2016)\end{array}$ & $\begin{array}{l}\text { Pengaruh portfolio } \\
\text { turnover }\end{array}$ & $\begin{array}{c}\text { Expense ratio berpengaruh } \\
\text { positif signifikan } \\
\text { Portfolio turnover } \\
\text { berpengaruh negatif tidak } \\
\text { signifikan }\end{array}$ \\
\hline 5 & & Pengaruh expense ratio & $\begin{array}{c}\text { Expense ratio berpengaruh } \\
\text { negatif signifikan }\end{array}$ \\
\hline
\end{tabular}




\begin{tabular}{|c|c|c|c|}
\hline & $\begin{array}{c}\text { Dharmastuti \& } \\
\text { Dwiprakasa, } \\
(2016)\end{array}$ & Pengaruh turnover ratio & $\begin{array}{c}\text { Turnover ratio berpengaruh } \\
\text { positif signifikan }\end{array}$ \\
\hline 6 & Lidyah, (2017) & $\begin{array}{c}\text { Pengaruh expense ratio } \\
\text { Pengaruh portfolio } \\
\text { turnover }\end{array}$ & $\begin{array}{c}\text { Expense ratio tidak } \\
\text { berpengaruh signifikan } \\
\text { Portfolio turnover tidak } \\
\text { berpengaruh signifikan }\end{array}$ \\
\hline
\end{tabular}

Sumber: Jurnal Diolah (2019)

Penelitian ini menggunakan 30 sampel reksa dana saham selama periode 20162018 dan melihat ketersediaan data melalui prospektus pembaharuan reksa dana yang tersedia pada Otoritas Jasa Keuangan (OJK) dan website reksa dana (bareksa dan pasar dana). Sedangkan penelitian terdahulu cenderung mengunakan reksa dana saham yang dapat dilihat dari penelitian yang dilakukan oleh See dan Jusoh (2012). Dimana penelitian tersebut menggunakan 69 reksa dana saham yang berada pada Malaysia dengan menggunakan metode Jensen selama periode 2005-2009. Selanjutnya berdasarkan penelitian yang dilakukan oleh Putri dan Haryanto (2014) menggunakan 12 reksa dana saham jenis KIK atau 60 observasi dari periode 1 Januari 2009-31 Desember 2013.

Berdasarkan penelitian yang dilakukan oleh Mulyawan (2016) menggunakan 27 sampel reksa dana syariah yang didasarkan pada reksa dana syariah yang aktif diperdagangkan pada periode januari 2010 hingga desember 2013. Selanjutnya pada penelitian yang dilakukan oleh Satrio dan Mahfud (2016) menggunakan sampel sebanyak 135 selama periode 2012-2014, melihat ketersediaan data berdasarkan situs resmi 0JK dan melihat ketersediaan data berdasarkan prospektus pembaharuan atau tahunan yang diterbitkan oleh masing-masing reksa dana.

Penelitian yang dilakukan oleh Dharmastuti \& Dwiprakasa, (2016) menggunakan pendekatan yang dilakukan oleh Sharpe dengan sampel sebanyak 34 reksa dana yang terdaftar pada website (pusat data kontan dan BI) dan melihat ketersediaan laporan keuangan reksa dana dari periode 20122013 yang dapat diakses. Selanjutnya berdasarkan penelitan yang dilakukan oleh Lidyah, (2017) menggunakan 12 sampel reksa dana saham yang terdaftar di OJK, memiliki kelengkapan laporan NAB, NAB diatas 500 miliar dan ditentukan berdasarkan sampel yang representatif.

Perbedaan penelitian ini dengan penelitian terdahulu pada sampel yang berjumlah 30, dengan menggunakan teknik purposive sampling, dan periode 2016-2018 yang diambil peneliti pada penelitian ini. Penelitian ini menggunakan purposive sampling dikarenakan teknik sampling yang digunakan adalah non random atau peneliti yang yang menentukan pengambilan sampel dengan menentukan ciri-ciri khusus dalam pengambilan data, sehingga sesuai dengan tujuan penelitian yang diharapkan.

Penelitian ini melihat pada faktor expense ratio dan portfolio turnover berasal dari aspek reksa dana saham. Sehingga penelitian ini akan diteliti dari sisi kinerja dalam bentuk return reksa dana saham yang disampaikan oleh perusahaan investasi yang menawarkan produk reksa dana saham dan manajer 
investasi yang mengelola reksa dana saham tersebut. Kemudian pemasalahan penelitian disimpulkan pada expense ratio, portfolio turnover berpengaruh terhadap tingkat return reksa dana saham. Dengan demikian pertanyaan penelitian yang menjadi dasar adalah bagaimana expense ratio, portfolio turnover berpengaruh dengan return reksa dana saham? Atas dasar persoalan dan pertanyaan penelitian tersebut, penelitian ini bertujuan untuk menguji pengaruh expense ratio, portfolio turnover, terhadap return pada reksa dana saham. Hasil penelitian diharapkan bermanfaat secara praktis bagi investor dan manajer investasi sebagai bahan masukan untuk pelaporan reksa dana saham. Secara teoritis, penelitian ini dapat bermanfaat untuk memberikan landasan bagi para peneliti lain dalam melakukan penelitian lain yang sejenis.

\section{Telaah Pustaka}

\section{Teori Portofolio}

Markowitz (1952) menyatakan dalam pendapatnya bahwa portfolio terdapat dua pendekatan portfolio investasi, meliputi pendekatan klasik dan pendekatan portfolio modern. Pendekatan klasik berfokus pada efisiensi pada investasi, pada pendekatan ini menggunakan analisis rata-rata varians untuk melihat dan membentuk portfolio yang efisien. Pendekatan klasik juga dapat memberikan imbal dari pada hasil tertinggi untuk tingkat risiko tertentu. Pendekatan portfolio modern berfokus pada asumsi bahwa investor sudah mengeluarkan sejumlah uang untuk investasi masa kini. Teori portfolio modern menjadi pedoman dalam mendukung keputusan alokasi untuk reksa dana, dana pension, dan Lembaga lain yang mencari imbalan dari pada hasil investasi portfolio yang maksimal dan meminimumkan risiko yang ada.

Penelitian ini menggunakan teori portofolio karena pada teori portofolio sangat mendasari dengan melihat pergerakan pasar pada reksa dana saham yang sejalan dengan pergerakan naik turunnya saham untuk melihat se-efesien mungkin dan se-optimal mungkin reksa dana saham mempengaruhi pelaporan reksa dana saham. Teori portofolio juga dapat melihat kinerja pada reksa dana saham untuk meminimalkan risiko yang ada dan memaksimalkan investasi portofolio sehingga dapat menurunkan risiko yang ada. Teori portofolio juga sangat berkaitan dengan estimasi pada investor yang menginvestasikan modalnya pada reksa dana saham. Sehingga dengan adanya teori portofolio dapat melihat return dari pada expense ratio dan portfolio turnover yang dapat mempengaruhi pelaporan reksa dana saham.

\section{Reksa Dana}

Berdasarkan Undang-Undang Pasar Modal No 8 Tahun (1995) pasal 1 ayat 27, didefinisikan bahwa reksa dana sebagai wadah yang dipergunakan untuk menghimpun dana dari masyarakat pemodal untuk selanjutnya diinvestasikan dalam portofolio efek oleh manajer investasi. Ada tiga hal yang terkait dari definisi tersebut yaitu: adanya dana dari masyarakat pemodal yang diinvestasikan ke reksa dana, dana yang diinvestasikan dapat berupa investasi dalam portofolio efek, dan dana yang diinvestasikan kemudian akan dikelola 
oleh manajer investasi. Berdasarkan Undang-Undang Pasar Modal No 8 Tahun (1995), pasal 18 ayat 1, reksa dana memiliki 2 bentuk: perseroan; atau kontrak investasi kolektif.

Berikut penjelasan klasifikasi reksa dana menurut Rumintang dan Azhari (2015): 1. Reksa dana saham, merupakan reksa dana yang diinvestasikan minimal $80 \%$ dari portofolio dalam efek yang bersifat ekuitas. 2. Reksa dana pasar uang, merupakan reksa dana yang aktivitas investasinya $100 \%$ pada efek pasar uang. 3. Reksa dana pendapatan tetap merupakan reksa dana yang diinvestasikan minimal $80 \%$ dari portofolio yang bersifat utang. 4 . Reksa dana campuran, merupakan reksa dana yang memiliki batasan investasi yang diberlakukan pada efek utang dan alokasi yang bersifat fleksibel.

Informasi laporan keuangan sangatlah penting dalam reksa dana, pada setiap reksa dana, laporan keuangan disajikan dalam bentuk prospektus pembaharuan dan fund fact sheet yang disajikan oleh manajer investasi. Reksa dana menerbitkan prospektus dalam 2 bentuk. Pertama, prospektus adalah laporan yang diterbitkan bersamaan dengan terbitnya reksa dana pertama kali (seluruh biaya ditanggung oleh Manajer Investasi). Kedua, prospektus pembaharuan Kinerja informasi laporan keuangan pada prospektus pembaharuan adalah laporan yang diterbitkan setiap tahun, setelah reksa dana memiliki usia lebih dari 1 tahun atau berakhirnya periode keuangan (biaya prospektus pembaharuan ditanggung oleh reksa dana).

Prospektus pembaharuan terdapat laporan keuangan reksa dana yang telah diaudit oleh auditor independen. Pada prospektus pembaharuan terdapat 2 rasio yaitu, ratio beban berdasarkan beban atau biaya operasional dan rasio perputaran portofolio (Rudiyanto, 2016).

\section{Expense ratio}

Expense ratio adalah total biaya yang dikeluarkan untuk kegiatan operasional perusahaan yang terdiri dari biaya administrasi dan manajemen untuk menunjuang operasional reksa dana (Satrio \& Mahfud, 2016). Expense ratio sebagai rasio pengeluaran manajemen, mengukur berapa banyak aset dana yang digunakan untuk administrasi dan biaya operasional lainnya. Expense ratio sendiri ditentukan dengan membagi biaya operasi dana dengan nilai ratarata aktiva reksa dana saham yang dikelola (Kenton dan Hayes, 2019). Sedangkan Champagne, et al, (2017) menyatakan bahwa expense ratio sebagai suatu rasio total aset bersih yang dibayarkan pemegang saham untuk biaya operasional dana.

\section{Portofolio Turnover}

Portfolio turnover adalah perbandingan antara nilai pembelian atau penjualan portofolio dalam satu periode dengan rata-rata nilai aktiva bersih dalam satu tahun. Portfolio turnover juga sebagai ukuran seberapa sering aset dalam dana dibeli dan dijual oleh manajer. Pengukuran biasanya dilaporkan untuk periode waktu dua belas bulan (Chen, 2018). Champagne, et al., (2017) menyatakan bahwa portfolio turnover sebagai pembanding antara penjualan atau 
pembelian, yang dapat dibagi dengan rata-rata total pada aset bersih 12 bulan dari dana tersebut dan menangkap dampak arus (baik arus masuk maupun keluar) dan mengimbangi perdagangan pada aktivitas perdagangan portofolio sehingga arus dan offset perdagangan berdampak pada aktivitas portfolio turnover.

\section{Return Reksa Dana Saham}

Return reksa dana saham adalah imbalan atau pengembalian yang diperoleh dimasa mendatang yang didapatkan dari pada proses investasi reksa dana saham. return reksa dana saham dapat dilihat dari nilai aktiva bersih perusahaan yang telah ditentukan oleh manajer investasi pada setiap reksa dana saham sehingga menjadi tolak ukur perusahaan. Indikator pengukuran reksa dana saham dilihat dari nilai aset bersih dalam jangka waktu periode tertentu.

Pengukuran reksa dana dapat memberikan keuntungan dari skala ketetapan waktu dan ketersediaan informasi yang terkandung pada reksa dana saham. Reksa dana yang memiliki pengukuran yang lebih besar, berarti memiliki keungulan dari transaksi yang memadai, sehingga ketika volume menunjukkan posisi yang lebih tinggi maka dapat menyebabkan pembelian yang dilakukan oleh broker dapat dikecilkan dengan standar dan peraturan yang berlaku (Dharmastuti dan Dwiprakasa, 2016).

Kemampuan kinerja manajer investasi dapat mempengaruhi saham-saham yang berada pada nilai pasar yang rendah dengan memanfaatkan skill yang dimiliki manajer investasi, sehingga dapat meningkatkan produktifitas reksa dana saham perusahaan. Reksa dana dapat memiliki kinerja yang baik ketika nilai aktiva bersih (NAB) dan indeks saham gabungan (IHSG) menunjukkan hasil yang baik, sehingga para investor akan mengambil keputusan investasinya dengan melihat hasil dari manajer investasi yang berada di IHSG dan nilai aktiva bersih (Juniar dan Rachmah, 2018).

\section{Pengembangan Hipotesis}

\section{Pengaruh Expense Ratio terhadap Return Reksa Dana Saham}

Expense ratio dapat diartikan sebagai aktivitas yang dilakukan oleh manajer investasi dalam menjalankan suatu reksa dana dengan melihat seberapa tinggi dan mahal manajer investasi menjalankan aktivitas reksa dana. Expense ratio didalamnya meliputi beban operasi dalam satu tahun dan rata-rata aset bersih dalam satu tahun. Hal ini sependapat dengan penelitian Harjono et al., (2017) yang menyatakan expense ratio dipengaruhi oleh biaya operasional yang dilakukan perusahaan, sehingga ketika semakin tinggi biaya yang dikeluarkan reksa dana, maka semakin tinggi expense ratio yang dihasilkan oleh reksa dana karena biaya yang dibebankan memiliki tingkat expense ratio yang tinggi.

Filip dan Karas (2018) mengemukakan bahwa expense ratio berpengaruh terhadap return dana, yang dapat ditunjukkan ketika skala dari ekonomi tersebut besar, maka akan terjadi kenaikan biaya yang dibebankan selama investasi yang dilakukan. Lidyah (2017) menyatakan bahwa ketika expense 
ratio mengalami peningkatan, maka kinerja reksa dana saham akan meningkat. Berdasar Fama dan French (2010) menyatakan bahwa ketika biaya yang disajikan dalam bentuk expense ratio tinggi, maka semakin besar expense ratio dari pada reksa dana tersebut hipotesis dibangun. Oleh karena itu, hipotesis sebagai berikut:

$\boldsymbol{H}_{1}$ : Expense ratio berpengaruh terhadap return reksa dana saham.

\section{Pengaruh Portfolio Turnover Terhadap Return Reksa Dana Saham}

Portfolio turnover dapat diartikan sebagai rasio perputaran yang aktivitas pembelian dan penjualan menunjukkan aktivitas yang tinggi dengan tingkatan frekuensi perputarannya yang tinggi juga. Portfolio turnover didalamnya meliputi aset reksa dana saham yang biasanya dalam bentuk prospektus pembaharuan reksa dana saham. Harjono et al. (2017) menyatakan bahwa reksa dana yang melakukan aktivitas trading, memiliki tingkat portfolio turnover yang lebih tinggi, dikarenakan semakin tinggi portfolio turnover, maka semakin tinggi kinerja yang dihasilkan oleh reksa dana tersebut.

Kemudian, Rumintang dan Azhari (2015) dengan menggunakan metode Sharpe dan Treynor, rasio menunjukkan bahwa portfolio turnover dalam semua reksa dana saham syariah yang diteliti, memiliki tingkat portfolio turnover yang tinggi dari SBIS sebagai investasi bebas risiko. Portfolio turnover perusahaan dilihat dari masa jabatan manajer sama atau kurang dari 10 tahun mengakibatkan manajer memiliki keterampilan portfolio turnover yang tinggi, sehingga manajer manajer memiliki kecenderungan yang tinggi dalam mengimplepentasikan strategi investasi yang baik (Amadi dan Y. Amadi 2017).

Portfolio turnover memiliki pengaruh positif terhadap kinerja reksa dana saham, yang menunjukkan semakin besar ukuran reksa dana, maka semakin baik portfolio turnover reksa dana saham tersebut ditunjukkan (Dharmastuti dan Dwiprakasa 2016). Oleh karena itu, hipotesis sebagai berikut:

$\boldsymbol{H}_{2:}$ Portfolio turnover berpengaruh terhadap return reksa dana.

\section{Metoda}

\section{Jenis dan Sumber Data}

Jenis penelitian yang digunakan penelitian ini merupakan kuantitatif berdasarkan data sekunder dengan pemilihan sampel menggunakan metode purposive sampling dengan model regresi linear sederhana. Penelitian ini menentukan populasi dan sampel dari seluruh reksa dana saham dari periode 2016-2018. Kriteria yang digunakan dalam penelitian ini dari reksa dana saham yang aktif dan terdaftar di OJK dan website (bareksa dan pasar dana) dari ketersediaan data yang sesuai dengan periode penelitian lengkap dari periode 2016-2018, data yang digunakan dilihat dari faktor manajer investasi dan berbasis informasi akuntansi. 
Penelitian ini menggunakan data yang bersumber dari reksa dana saham yang aktif dan terdaftar di OJK dan website (bareksa dan pasar dana). Penelitian ini juga menggunakan data return reksa dana saham, expense ratio dan portfolio turnover yang dirata-rata selama periode 2016-2018. Selanjutnya data extream, akan dikeluarkan outlier-nya untuk mendapatkan hasil yang lebih baik.

Teknik purposive sampling yang digunakan penelitian ini berdasarkan kriteria (1) reksa dana saham yang aktif pada 0JK dan website (bareksa dan pasar dana) pada periode 2016-2018. (2) reksa dana saham masih beroperasi hingga tahun yang digunakan dalam penelitian. (3) ketersediaan data berdasarkan prospektus pembaharuan yang memiliki laporan keuangan yang telah diaudit oleh auditor independen pada reksa dana saham.

Pemilihan model sampel dalam estimasi penelitian ini menggunakan regresi linear dengan menggunakan regresi linear berganda. Pemilihan sampel melihat pertimbangan ketersediaan data yang berada pada OJK, portal reksa dana, bareksa, dan pasar dana pada tahun 2016-2018. Pemilihan sampel tersebut berdasarkan ketersediaan laporan keuangan reksa dana saham atau prospektus pembaharuan pada tahun tertentu dalam reksa dana saham, dikarenakan tidak semua manajer investasi menyediakan laporan keuangan reksa dana atau prospektus pembaharuan secara lengkap.

Data yang diambil pada laporan keuangan atau prospektus pembaharuan reksa dana meliputi, nilai aktiva bersih, biaya operasional dan penjualan reksa dana yang berkategori konvensional dan ketersediaan data yang disajikan oleh manajer investasi dari setiap produk reksa dana saham yang aktif di Indonesia.

\section{Tabel 2. Pemilihan Sampel (2016-2018)}

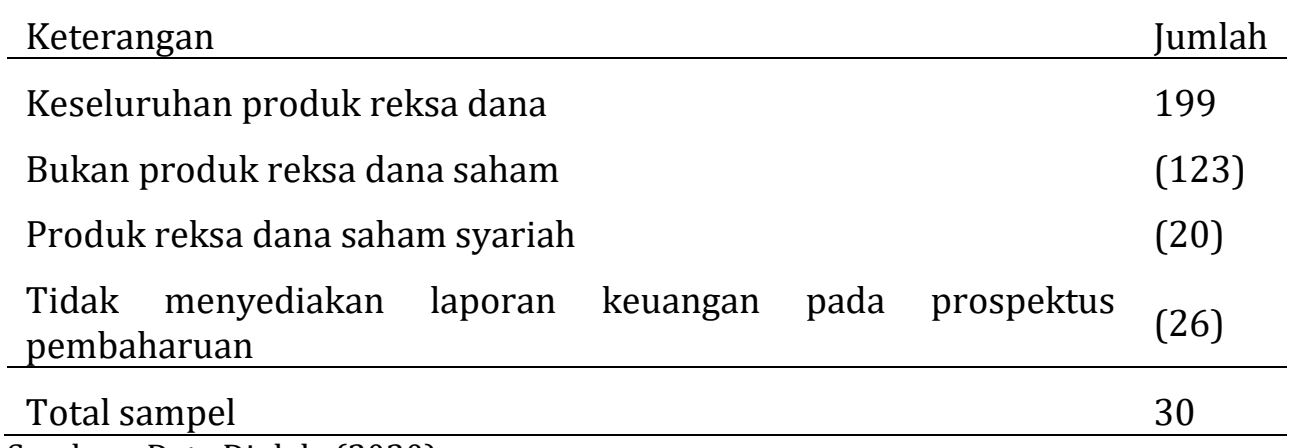

Sumber: Data Diolah, (2020)

\section{Teknik Analisis Data}

Uji hipotesis dari penelitian ini dengan menggunakan uji asumsi klasik dari uji normalitas, uji multikolinearitas, uji heteroskedastisitas, dan uji autokorelasi. Pengujian asumsi klasik ini, dilakukan untuk dapat memastikan bahwa data tidak memiliki gangguan dan layak untuk diuji lanjutan dalam penelitian ini dengan menggunakan SPSS. Pengujian hipotesis penelitian ini dengan analisis regresi linear dengan persamaan sebagai berikut:

$Y=\alpha+\beta E R+\beta P T+\varepsilon$ 


\section{Uji Asumsi Klasik}

Pengujian asumsi klasik sebagai berikut: (1) Uji Normalitas, bertujuan menguji model regresi variabel dependen dan independen, pada keduanya memiliki nilai distribusi yang normal atau tidak. (2) Uji Multikolinearitas, dengan adanya pengaruh yang sempurna antara beberapa atau semua variabel independen dari model regresi. Jika variabel bebas berkorelasi dengan sempurna, maka variabel tersebut dapat dikatakan dengan multikolinearitas. (3) Uji Autokorelasi, melihat model regresi, apakah ada korelasi antara kesalahan yang terjadi. (4) Uji Heterokedastisitas melihat variabel yang tidak sama untuk semua pengamatan pada model regresi.

\section{Definisi Operasional dan Pengukuran Variabel}

\section{Expense ratio}

Expense ratio merupakan rasio dari biaya operational reksa dana saham yang memiliki manfaat untuk aktivitas dan yang dibebankan terhadap aset dari pada reksa dana saham. Expense ratio pada umumnya dapat peroleh dalam prospektus reksa dana saham dan dalam format persentase dari pada aset dalam reksa dana saham tersebut (Dharmastuti dan Dwiprakasa, 2016). Informasi akuntansi expense ratio diukur ketika expense ratio memiliki nilai positif dalam perhitungannya, dapat diukur menggunakan total biaya reksa dana saham dan aktiva bersih reksa dana saham (Dharmastuti dan Dwiprakasa, 2016).

$$
\left(E R=\frac{\text { Biaya Operational }}{N A B}\right)
$$

\section{Portfolio turnover}

Portfolio turnover merupakan perbandingan antara pembelian dan penjualan reksa dana yang dilihat dari pengembalian pada suatu portfolio aset dalam aktivitas perdagangan yang dilakukan reksa dana saham dan tersedia pada prospektus pembaharuan reksa dana saham pada perusahaan reksa dana. Informasi portfolio turnover diukur ketika portfolio turnover reksa dana saham yang menunjukkan nilai positif dari perhitungan antara volume penjualan tertentu yang dilakukan dengan rata-rata aktiva pada reksa dana saham (Lidyah, 2017).

$$
\left(P T=\frac{\text { Penjualan }}{N A B} x 1\right)
$$

\section{Keputusan Hipotesis}

Pengukuran dari masing-masing variabel atas hasil analisis data panel dengan uji t pada output hasil analisis data. Berikut kriteria pengambilan keputusan: 
Bila $t_{\text {hitung }}>t_{\text {tabel }}$ atau profitabilitas $<$ tidak signifikan (Sig. $<0,05$ ), maka Ho ditolak atau Ha diterima (variabel independen berpengaruh terhadap variabel dependen).

Bila $t_{\text {hitung }}<t_{\text {tabel }}$ atau profitabilitas $>$ tingkat signifikansi (Sig. $\left.>0,05\right)$, maka Ho tidak ditolak atau Ha tidak diterima (variabel independen tidak berpengaruh terhadap variabel dependen).

Keseluruhan pengelolaan data yang dilakukan, terdapat pengujian hipotesis yang dilakukan dengan analisis:

\section{Uji Simultan (Uji F)}

Uji Statistik F digunakan untuk melihat apakah semua variabel independen atau bebas yang dimasukkan dalam model berpengaruh secara bersama-sama terhadap variabel dependen/terikat. Uji F dapat dilakukan dengan mengamati nilai signifikansi F. Apabila nilai signifikansi $\mathrm{F}<$ nilai signifikansi maka variabel independen berpengaruh secara bersama-sama terhadap variabel dependennya (Sugiyono, 2013).

\section{Uji Parsial (Uji t)}

Uji Statistik t digunakan untuk menguji seberapa jauh pengaruh satu variabel penjelas/independen secara parsial dalam dalam membandingkan $t_{\text {tabel }}$ dan $t$

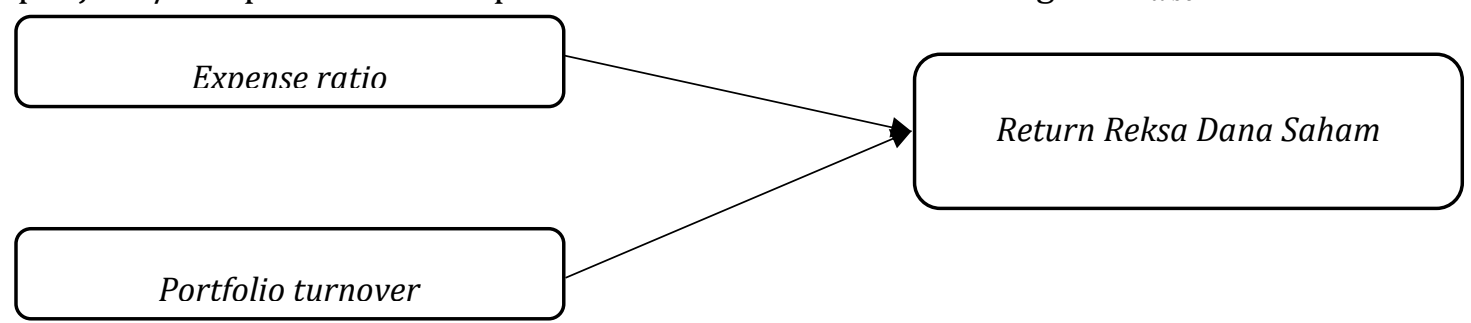

hitung. Uji t dapat dilakukan dengan mengamati nilai signifikansi t pada tingkat yang digunakan, yaitu 0,05. Apabila nilai signifikansi $t<0,05$, maka variabel independen berpengaruh secara signifikan terhadap variabel dependennya (Sugiyono, 2013).

\section{Gambar 1. Kerangka Hipotesis}

\section{Hasil dan Pembahasan}

\section{Gambaran Umum Objek Penelitian}

Penelitian ini menggunakan 30 sampel reksa dana saham yang terdaftar dalam OJK. Pemilihan sampel didasarkan pada teknik pengambilan sampel purposive sampling. Berdasarkan pengujian hasil asumsi klasik yang sudah dilakukan, dapat disimpulkan bahwa sampel telah terdistribusi normal, pengujian heteroskedastisitas menunjukkan bahwa tidak terjadinya heteroskedastisitas, pengujian autokorelasi menghasilkan tidak terjadi autokorelasi, dan dalam pengujian multikolinearitas menunjukkan bahwa tidak terjadi multikolinearitas pada penelitian ini. 


\section{Analisis Statistik Deskriptif}

Variabel yang digunakan pada penelitian ini meliputi expense ratio (ER) dan portfolio turnover (PT). Berdasarkan hasil variabel secara deskriptif dapat dilihat dibawah ini:

Tabel 3. Statistik Deskriptif

\begin{tabular}{ccccccc}
\hline Keterangan & $\mathrm{N}$ & Range & Minimum & Maximum & Mean & Std. Deviation \\
\hline ER & 30 & .56 & .03 & .59 & .2493 & .12959 \\
PT & 30 & 3.18 & .13 & 3.31 & 1.0680 & .74094 \\
Return & 30 & .12 & .02 & .14 & .0603 & .02484 \\
Valid N (listwise) & 30 & & & & & \\
\hline
\end{tabular}

Sumber: Data Diolah, (2020)

Berdasarkan hasil statistik deskriptif diatas menunjukkan bahwa nilai minimum expense ratio sebesar 0,03 , berasal dari nilai rata-rata reksa dana saham pada reksa dana saham Rencana Cerdas dari periode 2016-2018. Pada nilai maksimum expense ratio sebesar 0,59 , berasal dari reksa dana saham Bahana Dana Prima pada periode 2016-2018. Sehingga nilai mean dari pada expense ratio sebesar 0,2493 dengan standar deviasi sebesar 0,12959.

Berdasarkan hasil statistik deskriptif diatas menunjukkan bahwa nilai minimum dari portfolio turnover sebesar 0,13 , yang berasal dari nilai rata-rata reksa dana saham pada reksa dana saham BNI-Inspiring Equity Fund dari periode 2016-2018. Pada nilai maksimum reksa dana saham sebesar 3,31, yang berasal dari nilai rata-rata reksa dana saham pada reksa dana saham Schroder 90 Plus Equity Fund dari periode 2016-2018. Sehingga nilai mean dari pada portfolio turnover sebesar 1,0680 dengan standar deviasi sebesar 0,74094.

Berdasarkan hasil statistik deskriptif diatas menunjukkan nilai minimum return reksa dana saham sebesar 0,02 berasal dari nilai rata-rata return reksa dana saham pada reksa dana saham Schroder Dana Istimewah (pada tahun 2016 sebesar 0,04, tahun 2017 sebesar 0,03 dan tahun 2018 sebesar -0,01) dan nilai maksimum sebesar 0,14 berasal dari rata-rata return reksa dana saham pada reksa dana saham Simas Saham Unggulan (pada tahun 2016 sebesar 0,04, 2017 sebesar 0,06, dan 2018 sebesar 0,34). Sehingga nilai mean pada return reksa dana saham secara keseluruhan sebesar 0,0603 dengan standar deviasi sebesar 0,02484 .

\section{Hasil Uji Hipotesis}

Tabel 4. Hasil Regresi

\begin{tabular}{|c|c|c|c|c|c|c|}
\hline \multirow{2}{*}{\multicolumn{2}{|c|}{ Model }} & \multicolumn{2}{|c|}{$\begin{array}{l}\text { Unstandardized } \\
\text { Coefficients }\end{array}$} & \multirow{2}{*}{$\begin{array}{c}\text { Standardized } \\
\text { Coefficients } \\
\text { Beta }\end{array}$} & \multirow[t]{2}{*}{$\mathrm{t}$} & \multirow[t]{2}{*}{ Sig. } \\
\hline & & $\mathrm{B}$ & Std. Error & & & \\
\hline 1 & (Constant) & .080 & .011 & & 7.575 & .000 \\
\hline
\end{tabular}




\begin{tabular}{llllll}
\hline ER & -.089 & .033 & -.462 & -2.688 & .012 \\
PT & .002 & .006 & .055 & .322 & .750 \\
\hline
\end{tabular}

Sumber: Data Diolah, (2020)

Keterangan

ER: Expense ratio

PT: Portfolio turnover

Berdasarkan Ghozali, (2011:101) menjelaskan bahwa jika nilai signifikan < 0,05 maka memiliki arti variabel independen berpengaruh terhadap variabel dependen. Berdasarkan data diatas, nilai signifikansi dari ER menunjukkan $0,012<0,05$ yang memiliki arti expense ratio berpengaruh signifikan terhadap return reksa dana saham. Sedangkan PT memiliki nilai signifikan sebesar 0,750 $>0,05$ yang memiliki arti portfolio turnover tidak berpengaruh signifikan terhadap return reksa dana sana saham.

Berdasarkan $\mathrm{t}$ hit dan $\mathrm{t}$ tabel, menunjukkan bahwa nilai $\mathrm{t}$ tabel $(\alpha / 2 ; \mathrm{n}-\mathrm{k}-1)=$ $(0,05 / 2 ; 30-2-1)=(0,025 ; 27)=2.052$ dan $t_{\text {hit }}$ pada expense ratio sebesar $-2,688$ dan portfolio turnover sebesar 0,750 . Sehingga memiliki arti expense ratio berpengaruh kearah negatif terhadap return reksa dana saham $(-2,052>$ 2,688 ) dan portfolio turnover memiliki arti tidak berpengaruh tetapi memiliki arah yang positif terhadap return reksa dana saham $(2,052<0,322)$.

\section{Tabel 5. Uji F Signifikan}

\begin{tabular}{cccccccc}
\hline Model & $\mathrm{R}$ & R Square & $\begin{array}{c}\text { Adjusted R } \\
\text { Square }\end{array}$ & $\begin{array}{c}\text { Std. Error of } \\
\text { the Estimate }\end{array}$ & \multicolumn{3}{c}{ Change Statistics } \\
& & & & & R Square & $\mathrm{F}$ & Sig. F \\
Change & & Change \\
\hline \multirow{2}{*}{1} & $.460^{\mathrm{a}}$ & .211 & .153 & .02287 & .211 & 3.61 & .041 \\
& & & & & & & 4 \\
\hline
\end{tabular}

Sumber: Data Diolah, (2020)

Berdasarkan Ghozali, (2011:101) menjelaskan bahwa nilai signifikan uji f jika, signifikansi $<0,05$, sehingga memiliki arti variabel independen secara simultan berpengaruh terhadap variabel dependen. Berdasarkan data diatas menunjukkan bahwa nilai signifikansi f sebesar 0,041<0,05. Sehingga dapat diartikan bahwa expense ratio dan portfolio turnover, secara simultan berpengaruh terhadap return reksa dana saham.

Berdasarkan $f_{\text {hit }}$ dan $f_{\text {tabel }}$ menunjukkan bahwa $(\mathrm{k} ; \mathrm{n}-\mathrm{k})=(2 ; 28)=2$,99. Secara simultan nilai f expense ratio dan portfolio turnover sebesar 3,614 > 2,99. Sehingga memiliki arti bahwa expense ratio dan portfolio turnover secara simultan berpengaruh terhadap return reksa dana saham berdasarkan $\mathrm{f}$ tabel.

Berdasarkan $R$ square menunjukkan nilai sebesar 0,211, sehingga memiliki arti bahwa variabel expense ratio dan variabel portfolio turnover secara simultan berpengaruh terhadap return reksa dana saham sebesar 0,211 atau sebesar $21,1 \%$. 
Pada variabel expense ratio menunjukkan tingkat signifikan 0,012 dan memiliki, sehingga variabel $\mathrm{H}_{a}$ expense ratio diterima dan memiliki pengaruh kearah negatif terhadap return reksa dana saham. Ratio ini menunjukkan bahwa ketika semakin tinggi expense ratio, maka return reksa dana saham akan semakin rendah. Hal lain yang dapat mempengaruhi expense ratio negatif signifikan antara lain, ketika expense ratio mengalami kenaikan, maka return reksa dana saham akan menurun.

Hal ini dapat menyebabkan besarnya biaya yang dikeluarkan oleh manajer investasi dapat memotong return yang diberikan kepada investor karena sudah digunakan untuk kegiatan pembayaran beban yang terjadi. Apabila seorang manajer investasi melakukan aktifitas transaksi jual-beli saham, maka biaya yang dikeluarkan oleh manajer investasi akan besar untuk mendukung terjadinya kegiatan transaksi jual-beli reksa dana saham.

Berdasarkan penelitian terdahulu, penelitian ini sejalan dengan penelitian yang dilakukan oleh Dharmastuti dan Dwiprakasa, (2016) dan Putri dan Haryanto, (2014) yang menyatakan bahwa expense ratio berpengaruh secara negatif signifikan dikarenakan semakin besar biaya yang dikeluarkan, maka akan menurunkan tingkat return reksa dana saham itu sendiri. Hal ini juga dapat dikarenakan jika pasar efisien, maka reksa dana yang mengeluarkan biaya yang paling sedikit yang menunjukkan kinerja yang baik. Sedangkan jika pasar tidak efisien, maka reksa dana akan mengeluarkan biaya yang banyak dan dapat menyebabkan return yang lebih besar.

Penelitian ini juga sejalan dengan penelitian yang dilakukan oleh Mulyawan, (2016) yang menyatakan bahwa besarnya pengorbanan investor dalam melakukan investasi ditentukan oleh sebarapa mahal manajer investasi menetapkan tarif untuk mengelola reksa dana. Investor harus melihat seberapa besar dan kecilnya expense ratio sebelum berinvestasi, hal ini akan mempengaruhi besarnya return yang diterima investor.

Expense ratio berpengaruh negatif signifikan dikarenakan semakin besar expense ratio, maka akan mengurangi tingkat return dari investasi tersebut. Hal ini juga mempengaruhi tingakt efisensi yang rendah, sehingga dapat memengaruhi return yang diterima investor. Penelitian ini tidak sejalan dengan penelitian yang dilakukan oleh See dan Jusoh, (2012) yang menyatakan bahwa expense ratio tidak memiliki pengaruh yang signifikan terhadap return reksa dana saham.

Pada variabel portfolio turnover, menunjukkan tingakat signifikan sebesar 0,750 hal ini dikarenakan lebih besar dari nilai signifikansi 0,05 . Sehingga pada $\mathrm{H}_{\mathrm{a}}$ portfolio turnover tidak diterima yang menyebabkan portfolio turnover tidak berpengaruh terhadap return reksa dana saham. Hal ini dikarenakan portfolio turnover digunakan untuk perbandingan antara pembelian dan penjualan portfolio. Sedangkan yang dapat mempengaruhi portfolio turnover terhadap return reksa dana saham adalah market timing. Dikarenakan aktifitas market timing adalah melakukan aktifitas pembelian dan penjualan dan melihat seberapa sering dan banyak manajer investasi melakukan penjualan dan 
pembelian, sehingga hal ini dapat mempengaruhi return dari pada reksa dana saham yang ada.

Penelitian ini sejalan dengan penelitian yang dilakukan oleh Herwan et al.(2017) dan Lidyah (2017) yang menyatakan bahwa portfolio turnover dapat mempengaruhi tingkat hasil yang diterima pemegang unit penyertaan dan tingkat portfolio turnover yang tinggi, sehingga dapat dilihat dari kinerja keuangan yang lebih tinggi. Tidak ada pengaruhnya portfolio turnover dikarenakan portfolio turnover, hanya sebagai pembanding antara nilai penjualan dan pembelian, sehingga yang bisa mempengaruhi tingkat return reksa dana adalah market timing, dikarenakan market timing melakukan aktifitas pembelian dan penjualan reksa dana.

\section{Simpulan}

\section{Simpulan}

Penelitian ini bertujuan untuk menguji pengaruh antara expense ratio dan portfolio turnover terhadap return reksa dana saham. Berdasarkan hasil data yang diolah dan dianalisis, dapat diambil kesimpulan bahwa expense ratio berpengaruh signifikan tetapi memiliki arah yang negatif, dikarenakan semakin besar expense ratio, maka akan mengurangi tingkat return dari investasi tersebut. Hal ini dapat menyebabkan besarnya biaya yang dikeluarkan oleh manajer investasi dapat memotong return yang diberikan kepada investor karena sudah digunakan untuk kegiatan pembayaran beban yang terjadi.

Pada pengukuran portfolio turnover tidak berpengaruh signifikan terhadap return reksa dana saham. Hal ini dikarenakan portfolio turnover digunakan untuk perbandingan antara pembelian dan penjualan portfolio. Sedangkan yang dapat mempengaruhi portfolio turnover terhadap return reksa dana saham adalah market timing. Secara simultan, expense ratio dan portfolio turnover memiliki pengaruh terhadap return reksa dana saham pada periode 20162018.

\section{Keterbatasan dan Saran}

Ketersedian data pada keseluruhan reksa dana belum lengkap, misalnya prospektus pembaharuan reksa dana pada beberapa tahun tertentu tidak tersedia dan tidak disajikan pada website reksa dana yang tersedia (tidak semua perusahaan reksa dana menampilkan prospektus pembaharuan pada halaman website dan website pendukung reksa dana lainnya). Dengan demikian data dalam penelitian ini masih sangat terbatas.

Saran untuk penelitian-penelitian selanjutnya dapat memperluas sampel penelitian tidak hanya reksa dana saham, tetapi juga reksa dana obligasi, reksa dana campuran dan reksa dana pasar uang yang ada di Indonesia dan dapat meneliti hubungan antara expense ratio, portfolio turnover terhadap reksa dana di Indonesia. Penelitian selanjutnya juga, dapat memilih periode yang lebih panjang tidak hanya 3 tahun namun bisa 5 tahun bahkan 10 tahun. Kemudian 
penambahan variabel-variabel lain seperti stock selection, market timing, cash flow reksa dana, dan ukuran reksa dana dapat dilakukan.

\section{Daftar Pustaka}

Amadi, W., \& Amadi, F. Y. (2017). Another Look at Portfolio Turnover and Mutual Fund Performance. International Journal of Economics and Finance, 9, No.10.

Champagne, C., Karoui, A., \& Patel, S. (2017). Portfolio Turnover Activity and Mutual Fund Performance. The Journal of Finance, 17(4), 688. https://doi.org/10.2307/2977800

Chen, J. (2018). Portfolio https://www.investopedia.com/terms/p/portfolioturnover.asp

Dharmastuti, C. F., \& Dwiprakasa, B. (2016). Karakteristik Reksa Dana dan Kinerja Reksa Dana Saham di Indonesia. Jurnal Manajemen, 22(1), 94-116. https://doi.org/10.24912/je.v22i1.181

Fama, E. F., \& French, K. R. (2010). Luck versus Skill in the Cross-Section of Mutual Fund Returns. The Journal of Finance, LXV, No5, 1915-1947.

Fan, Y. (2016). Studies in Economics and Finance and Finance Renaissance. 24(1). https://doi.org/10.1108/10867371311325417

Filip, D., \& Karas, D. (2018). Expense Ratio as an Effect of Fund Attributes' Impact. Annales H - Oeconomia, LII, 4. https://doi.org/DOI:10.17951/h.2018.52.4.1727

Ghozali, I. (2011). Aplikasi Analisis Multivariate dengan Program SPSS. Badan Penerbit Universitas Diponegoro.

Harjono, T. H., Susilawati, C. E., Joko, F. X. A., \& Prabowo, W. (2017). Biaya Operasional Reksadana Sebagai Interverning Pengaruh Karakteristik Reksadana Terhadap Kinerja Reksadana Saham di Indonesia. Kajian Ilmiah Mahasiswa Manajemen (KAMMA), 6(2).

Herwan, T., Syafitri, Y., \& Elizabeth, S. M. (2017). Analisis Faktor-Faktor yang Mempengaruhi Kinerja Reksa Dana Saham di Indonesia Periode Tahun 20132015. STIE MDP.

Indonesia, R. (1995). Undang-Undang Republik Indonesia Nomor 8.Tahun 1995. In Undang-Undang Republik Indonesia (pp. 1-69).

Juniar, A., \& Rachmah, D. A. (2018). Analisis Pengaruh Stock Selection Skill, Market Timin Ability, dan Fund Longevity Terhadap Kinerja Reksadana Saham Syariah. Jurnal Sains Manajemen Dan Kewirausahaan, 2(1), 61-69.

Kenton, W., \& Hayes, A. (2019). Expense ratio. https://www.investopedia.com/terms/e/expenseratio.asp

KSEI. (2018). Berita Pers 21 Tahun KSEI: Inovasi untuk Kenyamanan Transaksi di Pasar Modal. $\quad$ Www.Ksei.Co.Id. www.ksei.co.id/.../156_berita_pers_21_tahun_ksei_inovasi_untuk_kenyamana n_transaksi_di_pasar_modal

Lidyah, R. (2017). Pengaruh Total Aset, Expense Ratio, dan Portfolio Turnover terhadap Kinerja Reksadana Saham di Indonesia. I-Economic, 3, No.1.

Lohana, P. M. (2013). Performance Evaluation of Selected Mutual Funds. Pacific Bussiness Review International, Vol 5(7), 60-66. 
Markowitz, H. M. (1952). Portfolio Selection. Journal of Finance, 7(1), 72-91. https://doi.org/https://dx.doi.org/10.1111/j.1540-6261.1952.tb01525.x

Mulyawan, S. (2016). Kinerja reksa dana syariah dan beberapa faktor yang memengaruhinya: studi di pasar modal Indonesia 2010-2013. Wacana Hukum Islam Dan Kemanusiaan, 16, No.2. https://doi.org/doi :10.18326/ijtihad.v16i2.217-236

Putri, C. H. M., \& Haryanto, A. M. (2014). Analisis Pengaruh Market Timing Ability, Stock Selection, Expense Ratio dan Tingkat Risiko terhadap Kinerja Reksa Dana Saham. Diponegoro Journal of Management, 1-10.

Rudiyanto. (2016). Mengenal Laporan Keuangan Reksa Dana. In Seri Panduan Investasi Reksa Dana untuk Pemula (p. 232).

Rumintang, A. G., \& Azhari, M. (2015). Analisis Perbandingan Kinerja Reksa Dana Saham Konvensional dan Reksa Dana Saham Syariah dengan Menggunakan Metode Sharpe, Treynor, dan Jensen Pada Tahun 2014. 2(2), Hal 1430.

Sari, A. P. N., \& Purwanto, A. (2012). Analisis Kebijakan Alokasi Aset, Kinerja Manajer Invetasi dan Tingkat Risiko Terhadap Kinerja Reksadana Saham di Indonesia. Diponegoro Journal of Accounting, 1(1), 1-14.

Satrio, Y., \& Mahfud, M. K. (2016). Analisis Fund Size, Expense Ratio, Turnover Ratio, Fund Age, dan Cash Flow Terhadap Kinerja Reksa Dana Saham di Indonesia (Studi Kasus: Reksa Dana Konvensional Berbasis KIK Tahun 2012-2014). Universitas Diponegoro, 5, No.2, 1-9.

See, Y. P., \& Jusoh, R. (2012). Fund Characteristics and Fund Performance: Evidance of Malaysian Mutual Fund. International Journal of Economics and Management Sciences, Volume 1, 31-43.

Sugiyono. (2013). Metode Penelitian Pendidikan Pendekatan Kuantitatif, Kualitatif, dan $R \& D$. Alfabeta.

Wibowo, A. (2011). Pengaruh Variabel Makro Ekonomi terhadap Kinerja Reksadana Pendapatan tetap di Indonesia. Jurnal Akuntansi, Manajemen Bisnis Dan Sektor Publik (JAMBSP), Vol 7(ISSN 1829-9857), 163-182. 